\title{
Does Environmental Management Accounting Matter in Promoting Sustainable Development? A Study in Iraq
}

\author{
Hutham Falih Chichan ${ }^{1}$, Hussein kareem mohammed ${ }^{2}$, Tariq Tawfeeq Yousif Alabdullah ${ }^{3}$
}

Accounting Techniques Department, Technical Institute for Administration, Middle Technical University, Iraq ${ }^{1}$, Madenat Alelem University College, Iraq ${ }^{2}$, Accounting Department, College of Administration and Economics, University of Basrah, Iraq

Purpose of this study is to examine the extent to which Iraqi industrial companies are aware of the concept of environmental management accounting (EMA), to examine the role of EMA in providing information that might influence decisions related to environmental protection and preservation of natural resources to contribute to the development of sustainable development. A sample of Iraqi industrial firms was surveyed by distributing a questionnaire to a random sample of the research community in the context of Iraqi firms. In addition, it also considers the social dimensions of sustainable development and the economy. The resolution data were analyzed using a statistical program (SPSS). When analyzing the data, the findings of the current study indicate that Iraqi industrial companies have an awareness of environmental management accounting concepts. In addition it provides information that contributes to the promotion of sustainable development. This study recommends the need to implement environmental management accounting (EMA) in Iraqi industrial companies because of its important role in providing information that leads to the reduction of negative environmental impacts resulting from the practice of its activities.

ISSN 2548-3501 (online)

Edited by:

Eny Maryanti

Reviewed by:

Dr. Dr. Basel J. A. ALi

${ }^{*}$ Correspondence: Hutham Falih Chichan

Received: 15 April 2021 Accepted: 20 June 2021 Published:31 July 2021

Citation: Chichan, mohammed and Alabdullah (2021) hothamfaleh@gmail.com

Does Environmental Management Accounting

Matter in Promoting Sustainable Development? A Study in Iraq
Keywords: : Environmental Management Accounting, Sustainable Development

Tujuan dari penelitian ini adalah untuk menguji sejauh mana perusahaan industri Irak menyadari konsep akuntansi manajemen lingkungan (EMA), untuk menguji peran EMA dalam memberikan informasi yang mungkin mempengaruhi keputusan terkait dengan perlindungan lingkungan dan pelestarian sumber daya alam. untuk berkontribusi pada pembangunan pembangunan berkelanjutan. Sebuah sampel perusahaan industri Irak disurvei dengan menyebarkan kuesioner ke sampel acak dari komunitas penelitian dalam konteks perusahaan Irak. Selain itu, juga mempertimbangkan dimensi sosial dari pembangunan berkelanjutan dan ekonomi. Data resolusi dianalisis menggunakan program statistik (SPSS). Ketika menganalisis data, temuan studi saat ini menunjukkan bahwa perusahaan industri Irak memiliki kesadaran konsep akuntansi manajemen lingkungan. Selain itu memberikan informasi yang memberikan kontribusi untuk promosi pembangunan berkelanjutan. Penelitian ini merekomendasikan perlunya penerapan akuntansi manajemen lingkungan (Environmental Management Accounting/EMA) pada perusahaan industri Irak karena perannya yang penting dalam memberikan informasi yang mengarahpada pengurangan dampak negatif lingkungan yang dihasilkan dari praktik kegiatannya.

Keywords: Akuntansi Manajemen Lingkungan, Pembangunan Berkelanjutan 


\section{INTRODUCTION}

Misuse of natural resources and environmental degradation have become as a biggest problems facing the world. Although the problems of environment we have faced nowadays are not new, we have not begun to realize their elements until lately after noticing the effect of environmental degradation on the poorness in the development of economic. While available, natural resources are vulnerable to depletion as a result of misuse. Accordingly, the concept of sustainable development has arose, which meets the requisites of the current without compromising the capability of coming generations in order to meet their personal needs. Global regional and local attention to environmental issues and sustainable development has put pressure on economic units to be aware of their responsibilities towards society and the environment. These units are part of a larger socio-environmental and economic system with their operations affect society and the surrounding environment. Therefore, they must take into account this responsibility by reducing the negative environmental impacts of their economic activity, by applying environmental management accounting methods as an information system that enables users to obtain information which reflects the environmental performance of economic units. In doing so. The system also supports decisions that are instrumental in protecting the environment from environmental pollutants and protecting natural resources from waste and loss to promote sustainable development. The importance of this study lies in the effectiveness of the information provided by EMA for the users that can obtain information which reflects the environmental performance of economic units. Further, it helps in making environmentally impactful decisions to improve the environmental and financial performance of economic units, protect the environment, and conserve their natural resources to promote sustainable development.

This research has come with the serious problems in the whole world that have effected its environment and economy because of the unexpected pandemic that hit all the economy and health of the world Alabdullah et al, (2020). Recently, several studies have been done in the discipline of managerial accounting that reflect the importance of such a discipline in the enhancement of several positive things related to the world of business (e.g., Almashhadani 2021; Alabdullah, 2021, Alabdullah et al., 2021; Ahmed et al. , 2020; Ahmed et al. , 2019; Ahmed et al. , 2020; Alabdullah, 2019; Alabdullah, et al., 2016; Alabdullah, et al., 2014; Alabdullah, 2016; Alabdullah \& Ahmed, 2019; Alfadhl, et al., 2013). More specifically, there are studies investigated the extent to which economic units adopt environmental management accounting technology such as Yassin, (2013). A He explored changes in the practice of EMA, and the factors influencing the adoption of this method in Egyptian industrial companies. His study concluded that
Egyptian industrial firms do not adopt the method of EMA despite pressure to adopt it. Another study done by Chang, (2013) aimed to demonstrate the significance of applying the method of EMA in addressing environmental costs in three Taiwanese universities, and found a general absence of EMA as a instrument for managing the costs of environmental. Here we found a gap represented by a lack of efforts related to accounting environmental performance. Other studies have dealt with several aspects, including ferreira, et al., (2010) which aimed to use environmental management accounting and innovation strategy in commercial establishments. This study found that the use of EMA has a significant relationship with the innovation process but not in relation to the product, and there is no statistically significant relationship between strategy and administrative accounting. The study of Larojan \&Thevaruban (2014) aimed to find a relationship between environmental management accounting or environmental performance and corporate performance. It found a positive relationship between the application of environmental management accounting and the environmental performance of companies. What distinguishes this study is that it aims to test the role of EMA in providing information that affects decisions related to environmental protection and conservation of natural resources to promote sustainable development by surveying the opinions of a sample of decision makers in Iraqi industrial companies. Other studies also considered the managerial accounting but from another perspective in their impact of performance, economic and other aspects (e.g., Alabdullah et al., 2019; Alabdullah, 2017; Alabdullah, 2018; Alabdullah et al., 2020; Alabdullah et al., 2020; Alabdullah et al., 2018; Alabdullah et al., 2018; Alabdullah et al, 2014; Abushammalaet al, 2015; Ahmed et al, 2020; Nor et al, 2020; Alabdullah, 2016a; Ahmed et al, 2019; Alabdullah, 2016b; Alabdullah et al, 2014a,b)

EMA is one of the most significant relatively modern topics as a key source for improving environmentally sound industrial activities and their competitiveness, which has led to the spread and launch of green or environmentally friendly products. Birkin (1996) was the first to refer to this concept, and pointed out that EMA "is a direct growth of MA as management accountants might apply their experiences and also their skills to develop the quality of environmental data in the making a decision process related to valuation of the investment, capital budget preparation, and also strategic management "(Tsui, 2014).

The International Federation of Accountants in 1998 submitted a research entitled Environmental Management (EM) in Organizations. The study discussed the role of administrative accountants in the environmental management of economic units and the importance of their expertise in promoting sustainable development (Sylph, 2006). EMA was defined in the study as "managing economic performance and environmental via the implementation and development of environmentally relevant of the accounting systems and its practices that might involve auditing and reporting some firms. EM usually includes costs of 
life cycle, benefit assessment, cost accounting, and strategic planning for EM" (Deegan ,2002).

In 2001, a specialized working group of the US Sustainable Development Division presented a study entitled EMA Procedures and Principles, in which EMA was defined as "the process of identifying, compiling, estimating, analyzing and preparing internal reports and using flow information but physically, i.e. energy flows, materials, environmental cost information water, and other monetary information necessary to make traditional and environmental decisions within the organization (UNDSD, 2001). In 2005, IFAC issued a guide as an international guidance document, whose definition of the year (1998) was included with the definition of the specialized working group of the United Nations Sustainable Development Division (2001), in order to define environmental management accounting as "identifying, collecting and using two types of information to make internal decisions, material information that includes uses, water and materials, flows and trends of energy, with waste and financial information on environmental costs related to the environment." Profits, savings (IFAC, 2005). Based on the above, the current study developed these hypothesis:

H1: Iraqi industrial companies are aware of the concept of EMA. $\mathrm{H} 2$ : The application of EMA in Iraqi industrial companies contributes to providing information that promotes the economic, environmental and social dimensions of sustainable

\section{METHOD}

\section{Data collection}

The research followed the analytical descriptive approach, and was based in the theoretical framework on books, references and previous studies. On the practical side, the data was collected via a questionnaire based on previous studies, and the questionnaire was judged through academics to guarantee its apparent soundly, and distributed randomly to the research sample of people related to the subject matter of the research and whose decisions affect the environmental performance of the company. Likert Scale was utilized by the current study, and also we used SPSS was analyze data. A sample of the study consists of fifty-five Iraqi industrial companies; the questionnaire was randomly distributed to a sample of the research community of fifty questionnaires. Forty-five of them have been recovered for statistical analysis.

\section{RESULTS AND DISCUSSION}

\section{Analysis the study sample}

The demographic features of a study sample were analyzed in table 1
[Table 1 about here.]

Table (1) reveals that most of the study sample members are qualified in a high way and have advanced job positions and with high average of knowledge. This enhances confidence the questionnaire and its information.

\section{Test of Stability}

The (Alpha Cranach's) for all questions in the questionnaire is $(83.7 \%)$. It means that the stability factor for the questionnaire is high, as it is greater than $(60 \%)$.

\section{hypotheses Test}

One sample of the t-test analysis we used in the present study to test the hypotheses at significance level (0.05) and also for a confidence level of (0.95).

Testing the first hypothesis "Iraqi industrial companies are aware of the concept of environmental management accounting."

\section{[Table 2 about here.]}

Table (2) shows that the arithmetic mean of the first question (2.644) is less than (3) the average response score, and the standard deviation (1.524) is the highest deviation between the questions .The Significance level (0.125) is greater than (0.05), i.e. the decision is not moral for the first question, which is an incorrect definition of environmental management accounting, i.e. the respondents did not agree on this question. As for the arithmetic mean of the remaining questions is greater than (3) the average degree of response, and the Significance level $(0.000)$ is less than $(0.05)$, i.e. the decision for the remaining three questions is moral and is correct definitions of environmental administrative accounting. This gives evidence that the respondents were able to distinguish between the correct and incorrect definition of environmental management accounting.

The arithmetic mean for all questions (3.571) is higher than (3) average response score, and to accept the hypothesis we compare the computed $(\mathrm{t})$ value (6.971) which is greater than the Tabular $(\mathrm{t})$ value (2.000) and the Significance level (0.000) less than (0.05). So the first hypothesis is accepted.

Testing the second hypothesis "the application of environmental administrative accounting in Iraqi industrial companies contributes to providing information that enhances the economic, environmental and social dimensions of sustainable development

\section{[Table 3 about here.]}

Table (3) shows that the arithmetic mean of the economic dimension questions (4.018) is greater than (3) the average response score, and that the std. (0.430) has slight dispersion of values from its mean, indicating positive responses from the respondents to this dimension. The coefficient of variation for the third question $(9.153 \%)$, as it is the lowest coefficient of 
variation in the economic dimension, indicating that the optimal utilization of available resources in the best possible way is significantly influenced by the rest of the questions of the economic dimension with the information provided by environmental management accounting.

\section{[Table 4 about here.]}

Table (4) shows that the arithmetic mean of the environmental dimension questions (4.029) is greater than (3) the average response score, and that the Std. (0.401) has slight dispersion of values from its mean, indicating positive responses from the respondents to this dimension. The Coefficient of variation for the fifth question $(7.320 \%)$, as it is the lowest coefficient of variation in the environmental dimension, indicating that the Exclusion or reduction (neutralization) of productive activities and events with adverse effects on the environment (waste, residues, and emissions) is significantly influenced by the information introduced by EMA more than the other environmental dimension questions.

\section{[Table 5 about here.]}

Table (5) shows that the arithmetic mean of the social dimension questions (3.637) is greater than (3) the average response score, and that the Std. (0.501) has slight dispersion of values from its mean, indicating positive responses from the respondents to this dimension. The Coefficient of variation for the second question $(10.631 \%)$, as it is the lowest coefficient of variation in the social dimension, indicating that meeting consumer' needs and desires of environmentally friendly products is significantly influenced by the information provided by environmental management accounting more than the other social dimension questions.

\section{[Table 6 about here.]}

Table (6) shows that the arithmetic mean of the three dimensions (3.894) is greater than (3) the average response score, the standard deviation $(0.287)$ and is considered a little dispersion of values from its arithmetic mean, which indicates a positive response from the respondents. The Coefficient of variation of the environmental dimension $(9.952 \%)$ is the lowest factor, followed by the economic dimension $(10.701 \%)$ and finally the social dimension $(13.775 \%)$. It is clear that there is a large agreement from the respondents that the environmental dimension is the most affected by the information introduced by the application of EMA following the economic and social.

To accept the hypothesis, we compare the value of the computed $(\mathrm{t})$ value for the three dimensions (18.648), which is greater than the Tabular $(\mathrm{t})$ value (2.000) and the level of significance of the three dimensions $(0.00)$ is lower $(0.05)$, so the second hypothesis is accepted.

\section{CONCLUSION}

Environmental management accounting information is of great importance in supporting management decisions with environmental implications. Iraqi industrial companies are part of a larger socio-environmental and economic system, and by applying environmental management methods, they will play a role in achieving the optimal use of available resources, preserving the environment and achieving the wellbeing of society. In doing so, it will be able to promote the economic, environmental and social dimensions of development sustainability. The analysis of the questionnaire data showed that Iraqi industrial companies have an awareness of the concept of environmental management accounting and their role in supporting decisions that help conserve natural resources and protect the environment. The application of environmental management accounting provides appropriate information that promotes the dimensions of sustainable development and the most affected dimensions of the environmental dimension following the economic and finally the social dimension. This study recommended that Iraqi industrial companies should apply the environmental management accounting because of its importance in providing information that leads to reducing the negative environmental impacts resulting from the practice of their activities. This contributes to the conservation of natural resources, the protection of the environment and the promotion of sustainable development. Also Develop the skills of the managing accountant, and increase his understanding of environmental management accounting methods as a modern and important approach and use its information in the decision making-process

\section{REFERENCES}

Abushammala, S. N., Alabdullah, T. T. Y., \& Ahmed, E. R. (2015). Causal Relationship between Market Growth and Economic Growth. Comparison Study. European Journal of Business and Management 7(33).

Ahmed, E. R., Alabdullah, T. T. Y., Ardhani, L., \& Putri, E. (2021). The Inventory Control System's Weaknesses Based on the Accounting Postgraduate Students' Perspectives. Journal of Accounting and Business Education, 5(2), 1-8.DOI: http://dx.doi.org/10.26675/jabe.v5i2.19312.

Ahmed, E. R., Alabdullah, T. T. Y., Shaharudin, M. S., \& Putri, E. (2020). Further Evidence on the Link between Firm's Control Mechanisms and Firm Financial Performance: Sultanate of Oman. Journal of Governance and Integrity, 4(1), 1-6.

Ahmed, E. R., Alabdullah, T. T. Y., Thottoli, M. M., \& Maryanti, E. (2020). Does Corporate Governance Predict Firm Profitability? An Empirical Study in Oman. The 
International Journal of Accounting and Business Society, 28(1), 127-143.

Ahmed, E. R., Alabdullah, T. T. Y \& Shaharudin, M. S. (2020). Approaches to Control Mechanisms and Their Implications for Companies' Profitability: a Study in UAE. Journal of accounting Science, Vol. 4, no. 2, pp. 11-20.

Ahmed, E. R., Alabdullah, T. Y., Islam, M. A., \& Asmar, M. (2014) "Sukuk Legitimacy: A New Measurement Based on Content Analysis" 16th Malaysian Finance Association Conference in Sasana Kijang Central Bank of Malaysia, Kuala Lumpur, June 4-6, 2014.

Ahmed, E. R., Aiffin, K. H. B., Alabdullah, T. T. Y., \& Zuqebah, A. (2016). Zakat and Accounting Valuation Model. Journal of Reviews on Global Economics, 5, 16-24.

Ahmed, E. R., Islam, M. A., Alabdullah, T. T. Y., \& Amran, A. B. (2019). A qualitative analysis on the determinants of legitimacy of sukuk. Journal of Islamic Accounting and Business Research, Vol. 10 No. 3, pp. 342-368.

Alabdullah, T. T. Y. (2021). Management accounting insight via a new perspective on the risk management - companies' profitability relationship. International Journal of Intelligent Enterprise 7, In press.

Alabdullah, T. T. Y. (2019). Management Accounting and Service Companies' Performance: Research in Emerging Economies, Australasian Accounting, Business and Finance Journal, 13(4), 100-118.doi:10.14453/aabfj.v13i4.8.

Alabdullah, T. T. Y. (2017). Compensation committee, company board attributes, and company performance: The moderating effect of leadership position. Paper presented at the 2017 Wei International Academic Conference Proceedings, July 24-27, 2017, Business and Economics.

Alabdullah, T. T. Y. (2016a). Agency Theory Perspective: A Quantitative Study Of Accounting Performance Measures In Emerging Economies. ICTE Proceedings, New York.

Alabdullah, T. T. Y. (2016b). Are Board Size And Ownership Structure Beneficial In Emerging Markets' Firms? Evidence from Jordan. International Journal of Management \& Information Systems (IJMIS), 20(3), 87-94.

Alabdullah, T. T. Y. (2016c). Corporate Governance from The Perspective of The Past and The Present and The Need to Fill an International Gap. Risk Governance \& Control: Financial Markets \& Institutions, 6(4).

Alabdullah, T. T. Y. (2016d). The Performance of Companies and The Board's Characteristics From the New Perspective of Manipulation Avoidance. Corporate Ownership \& Control, 13(4), 279-286.

Alabdullah, T. T. Y., Yahya, S., \& Ramayah, T. (2014a). Corporate Governance Development: New or Old Concept? European Journal of Business and Management, 6(7), 312315.

Alabdullah, T. T. Y., Yahya, S., and T.Ramayah (2014b).
Corporate Governance Mechanisms and Jordanian Companies' Financial Performance. Asian Social Science 10, 247-247.

Alabdullah, T. T. Y., Alfadhl, M. M. A., Yahya, S., \& Rabi, A. M. A. (2014). The Role of Forensic Accounting in Reducing Financial Corruption: A Study in Iraq. International Journal of Business and Management, 9 (1), 26.

Alabdullah, T. T. Y., Ahmed, E. R., \& Ahmed, R. R. (2021). Organization features and profitability: Implications for a sample of Emerging Countries. Journal of Accounting and Business Education, 5(2), 43-52.DOI: http://dx.doi.org/10.26675/jabe.v5i2.16351.

Alabdullah, T. T. Y., Ahmed, E. R., and Nor, M. I. (2020). The World Declining Economy And Coronavirus Pandemic: Systems Should Be Continued. Russian Journal of Agricultural and Socio-Economic Sciences 102, 89-96. doi: 10.18551/rjoas.2020-06.11

Alabdullah, T. T. Y., Yahya, S., Nor, M. I., \& Majeed, F. Q. (2016). An Investigation of Corporate Governance from A New Perspective: Examining the Financial Performance of Companies and The Impact of Executive Turnover. Corporate Board: Role, Duties \& Composition, 12(1).

Alabdullah, T. T. Y., Ahmed, E. R. (2019). Board Diversity and Disclosure of Corporate Social Responsibility Link: A Study in Malaysia. Journal of Adv Research in Dynamic \& Control System, 11(11).

Alabdullah, T. T. Y., Ahmed, E. R., \& Muneerali, M. (2019). Effect of Board Size and Duality on Corporate Social Responsibility: What has Improved in Corporate Governance in Asia?. Journal of Accounting Science, 3(2), 121-135.

Alabdullah, T. T. Y. (2018). The relationship between ownership structure and firm financial performance. Benchmarking: An International Journal, 25(1), 319-333.

Alabdullah, T. T. Y., Laadjal, A., Ries, E., \& Al-Asadi, Y. A. A. (2018). Board Features and Capital Structure in Emerging Markets. Journal of Advanced Management Science, 6 (2).

Alabdullah, T. T. Y., Nor, M. I., \& Ahmed, E. R. (2018). The determination of firm performance in emerging nations: Do board size and firm size matter? Management, 5(3), 57-66.

Alabdullah, T. T. Y \& Ahmed, E. R. (2020). Audit Committee Impact on Corporate Profitability in Oman Companies: an Auditing and Management Accounting Perspective. Riset Akuntansi dan Keuangan Indonesia, Vol. 5, no. 2, pp. 121128.

Alabdullah, T. T. Y., Ahmed, E. R., \& Nor, M. I. (2019). Do board characteristics provide more enhancement for firm financial performance? A corporate governance perspective. New challenges in corporate governance: Theory and practice (pp. 89-91). https://doi.org/10.22495/ncpr 25.

Alabdullah, T. T. Y. and Ahmed, E. R. (2018). Corporate Governance: To What Extent it is important in the Arab 
Countries. International Journal of Science and Research 7.

Alabdullah, T. T. Y \& Ahmed, E. R. \& Abushammala, S. (2020). Growth of Companies: Empirical Study of the Companies Listed in Developing Economies. Journal of accounting Science, Vol. 4, no. 2, pp. 1-10.

Alfadhl, M. M. A., Alabdullah, T. T. Y. (2016). Agency Cost and Management Behavior: The Role of Performance as a Moderator. International Journal of Science and Research (IJSR), 5(1), 1858-1864.

Alfadhl, M. M. A. F. and Alabdullah, T. T. Y. (2013). Determinants of the Managerial Behavior of Agency Cost and Its Influential Extent on Performance: A Study in Iraq. International Journal of Humanities and Social Science, 33.

Almashhadani, M. (2021). How Dose Corporate GovernanceLEverage OrganizathonalIL Performance: A Survey With Suggesthon And Notes For Further Research. Russian Journal of Agricultural and Socio-Economic Sciences 3(111), 3-9.

Almashhadani, M. (2020). Testing the effecting elements of R\&D engineer's inventively in design industrialization Sector: A study in Singapore. Journal of Information and Computational Science, 10(5).

Chang, H.C., (2013)." Environmental management accounting in the Taiwanese higher education sector Issues and opportunities", International Journal of Sustainability in Higher Education Vol. 14.No .2.p 134.

Deegan, C. (2002), "Environmental Management Accounting Project", Case Study Subject: G H Michel \& Sons, the Commonwealth of Australia, EPA

Ferreira, Aldonio, Moulang, Carlym and Hendro, Bayu. (2010). Environmental management accounting and innovation: an exploratory analysis, Accounting, Auditing and Accountability Journal, 23 (7): 920-948

IFAC (International Federation of Accountants), (2005), "International Guidance Document - Environmental Management Accounting”, USA, New York.

Larojan, C, Thevaruban J, ( 2014), "Impact of Environmental Management Accounting Practices On Financial Performance Of Listed Manufacturing Companies in Srilanka "3rd International Conference On Management and Economics, 26 - 27 February.

Nor, M. I., Masron, T. A., \& Alabdullah, T. T. Y. (2020). Macroeconomic fundamentals and the exchange rate volatility: empirical evidence from Somalia. $S A G E$ Open, 10(1), 2158244019898841.

Sylph, Jim, (2006), "corporate Sustainable Management and Environmental Management Accounting”, Global Business Canters, Vol. (12), pp (10-14)

Tsui, Christophor S. K., (2014). , "A literature Review on Environmental Management Accounting (EMA) Adopting",
Web Journal of Chinese Management Review, Vol. (17), No. (3) August

UNDSD, United Nations Division for Sustainable Development, (2001) Environmental Management Accounting, Procedures and Principles, United Nations, New York.

Yassin, Mohamed Zaki, (2013). "Exploring Management Accounting Change in Egypt Informed by the Adoption of Environmental Management Accounting (EMA) in Industrial Companies" Unpublished PHD Dissertation, University of Essex.

Copyright (C) 2020 and. This is an open-access article distributed under the terms of the Creative Commons Attribution License (CC $B Y)$. The use, distribution or repro- duction in other forums is permitted, provided the original author(s) and the copy-right owner(s) are credited and that the original publication in this journal is cited, in accordance with accepted academic practice. No use, distribution or reproduction is permitted which does not comply with these terms. 


\section{LIST OF TABLES}

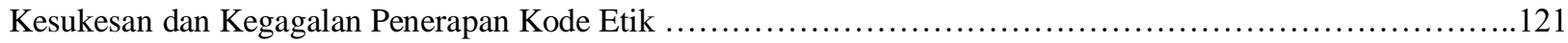

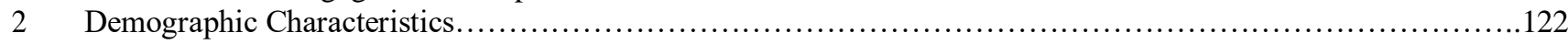

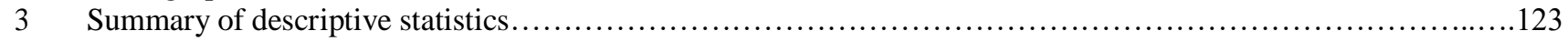

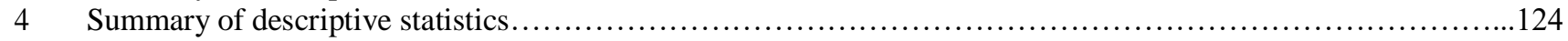

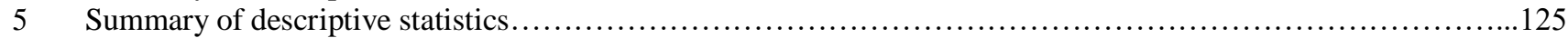

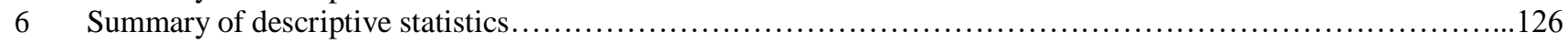


TABLE 1 | Demographic Characteristic

\begin{tabular}{|c|c|c|c|c|c|}
\hline $\begin{array}{l}\text { Academic } \\
\text { Achievement }\end{array}$ & Doctorate & Master & Bachelor & Diploma & Total \\
\hline Frequency & 2 & 6 & 32 & 5 & 45 \\
\hline Freq- Percentage & $4.44 \%$ & $13.33 \%$ & $71.11 \%$ & $11.12 \%$ & $100 \%$ \\
\hline Specialty & Accounting & $\begin{array}{l}\text { Business } \\
\text { Management }\end{array}$ & Others & ---- & Total \\
\hline Frequency & 30 & 7 & 8 & ------ & 45 \\
\hline Freq- Percentage & $66.67 \%$ & $15.55 \%$ & $17.78 \%$ & ------ & $100 \%$ \\
\hline Job Title & General Manager & Finance Director & Accountant & Cost accountant & Total \\
\hline Frequency & 4 & 20 & 11 & 10 & 45 \\
\hline Freq-Percentage & $8,89 \%$ & $44,45 \%$ & $24.44 \%$ & $22,22 \%$ & $100 \%$ \\
\hline Experience years & 5 and below & $6-10$ & $11-15$ & More than 15 & Total \\
\hline & & & & & 45 \\
\hline Frequency & --- & 5 & 17 & 23 & \\
\hline Freq-Percentage & ---- & $11.11 \%$ & $37,78 \%$ & $51.11 \%$ & $! 00 \%$ \\
\hline
\end{tabular}


TABLE 2 | Summary Descriptive Analysis

\begin{tabular}{|c|c|c|c|c|c|}
\hline Question & Mean & Std. Dev & T value & Sig & $\begin{array}{l}\text { Statisticl } \\
\text { Decision }\end{array}$ \\
\hline $\begin{array}{l}\text { EMA means the collection and identification } \\
\text { oinformation on environmental performance Financially } \\
\text { only and reaching out to users. }\end{array}$ & 2.644 & 1.524 & -1.564 & 0.125 & In moral \\
\hline $\begin{array}{l}\text { It is the method of identifying and collecting financial and } \\
\text { non-financial information on the flow of materials, } \\
\text { energy, water, and environmental and non-environmental } \\
\text { costs for internal decision-making purposes. }\end{array}$ & 3.777 & 0.559 & 9.324 & 0.000 & Moral \\
\hline $\begin{array}{l}\text { The application of environmental management } \\
\text { accounting is consistent with approved environmental and } \\
\text { accounting laws, legislation and standards. }\end{array}$ & 3.822 & 0.613 & 8.986 & 0.000 & Moral \\
\hline $\begin{array}{l}\text { EMA is the management of environmental and economic } \\
\text { performance via development and implementation } \\
\text { Environment-related practices and accounting systems. }\end{array}$ & 4.044 & 0.638 & 10.981 & 0.000 & Moral \\
\hline TOTAL & 3.571 & 0.556 & 6.971 & 0.000 & Moral \\
\hline
\end{tabular}


TABLE 3 | Summary Descriptive Analysis

\begin{tabular}{|c|c|c|c|c|c|c|}
\hline Question & Mean & Std. Dev & T value & $\begin{array}{l}\text { Coefficient of } \\
\text { variation }\end{array}$ & Sig & $\begin{array}{l}\text { Statisticl } \\
\text { Decision }\end{array}$ \\
\hline \multicolumn{7}{|l|}{$\begin{array}{l}\text { The application of environmental management } \\
\text { accounting contributes to: }\end{array}$} \\
\hline & 3.866 & 0.705 & 10.850 & $18.235 \%$ & 0.000 & Moral \\
\hline \multicolumn{7}{|l|}{$\begin{array}{l}\text { Achieving financial savings through Environmental } \\
\text { cost control for the company's operations and } \\
\text { products. }\end{array}$} \\
\hline $\begin{array}{l}\text { Achieving financial savings by reducing waste } \\
\text { treatment costs and industrial waste. }\end{array}$ & 4.400 & 0.458 & 10.407 & $10.409 \%$ & 0.000 & Moral \\
\hline $\begin{array}{l}\text { The best use of resources available in the best } \\
\text { possible way. }\end{array}$ & 3.911 & 0.358 & 17.064 & $9.153 \%$ & 0.000 & Moral \\
\hline Achieving financial savings by reducing resource & $3 . .822$ & 0.575 & 9.586 & $15.044 \%$ & 0.000 & Moral \\
\hline $\begin{array}{l}\text { Improve product quality and increase marketing rates } \\
\text { through reduce their environmental impacts from } \\
\text { design and development to use. }\end{array}$ & 4.200 & 0.502 & 7.416 & $11.952 \%$ & 0.000 & Moral \\
\hline $\begin{array}{l}\text { Get a competitive advantage to improve the quality } \\
\text { of products environmentally }\end{array}$ & 4.177 & 0.683 & 11.683 & $16.351 \%$ & 0.000 & Moral \\
\hline $\begin{array}{l}\text { Raising the efficiency of the economic unit through } \\
\text { optimal use for its environmental assets. }\end{array}$ & 3.755 & 0.645 & 7.857 & $17.177 \%$ & 0.000 & Moral \\
\hline Total & 4.018 & 0.430 & & $10.701 \%$ & $0.000-$ & Moral \\
\hline
\end{tabular}


TABLE 4 | Summary Descriptive Analysis

\begin{tabular}{|c|c|c|c|c|c|c|}
\hline Question & Mean & Std. Dev & T value & $\begin{array}{l}\text { Coefficient of } \\
\text { variation }\end{array}$ & Sig & $\begin{array}{l}\text { Statisticl } \\
\text { Decision } \\
\end{array}$ \\
\hline \multicolumn{7}{|l|}{$\begin{array}{l}\text { The application of environmental management } \\
\text { accounting contributes to: }\end{array}$} \\
\hline & 4.000 & 0.668 & 6.916 & $16.700 \%$ & 0.000 & Moral \\
\hline \multicolumn{7}{|l|}{$\begin{array}{l}\text { Producing environmentally friendly products } \\
\text { according to environmental quality standards. }\end{array}$} \\
\hline $\begin{array}{l}\text { Provide environmental performance data to } \\
\text { improve investment and operational decision- } \\
\text { making related to environmental activities. }\end{array}$ & 3.800 & 0.594 & 7.731 & $15.631 \%$ & 0.000 & Moral \\
\hline $\begin{array}{l}\text { Provide the necessary data to effectively manage } \\
\text { the process of dealing with negative environmental } \\
\text { impacts. }\end{array}$ & 4.022 & 0.453 & 9.101 & $11.263 \%$ & 0.000 & Moral \\
\hline $\begin{array}{l}\text { Efficient use of natural resources and available } \\
\text { energy by tracking their flow and preserving the } \\
\text { environment. }\end{array}$ & 3.755 & 0.484 & 10.470 & $12.889 \%$ & 0.000 & Moral \\
\hline $\begin{array}{l}\text { Exclusion or reduction (neutralization) of } \\
\text { productive activities and events with adverse effects } \\
\text { on the environment (waste, residues, and } \\
\text { emissions). }\end{array}$ & 4.822 & 0.353 & 9.101 & $7.320 \%$ & 0.000 & Moral \\
\hline $\begin{array}{l}\text { Study the potential environmental impacts of new } \\
\text { investment projects. }\end{array}$ & 3.777 & 0.735 & 7.097 & $19.459 \%$ & 0.000 & Moral \\
\hline Total & 4.029 & 0.401 & $\longrightarrow$ & $9.952 \%$ & 0.000 & Moral \\
\hline
\end{tabular}


TABLE 5 | Summary Descriptive Analysis

\begin{tabular}{|c|c|c|c|c|c|c|}
\hline Question & Mean & Std. Dev & T value & $\begin{array}{l}\text { Coefficient of } \\
\text { variation }\end{array}$ & Sig & $\begin{array}{l}\text { Statisticl } \\
\text { Decision }\end{array}$ \\
\hline \multicolumn{7}{|l|}{ The application of environmental management } \\
\hline & 3.600 & 0.579 & 6.940 & $16.083 \%$ & 0.000 & Moral \\
\hline \multicolumn{7}{|l|}{$\begin{array}{l}\text { Ensure the rights of future generations of available } \\
\text { natural resources }\end{array}$} \\
\hline $\begin{array}{l}\text { Meet consumers' needs and desires of environmentally } \\
\text { friendly products. }\end{array}$ & 3.800 & 0.404 & 13.266 & $10.631 \%$ & 0.000 & Moral \\
\hline $\begin{array}{l}\text { Improving the health reality of individuals by } \\
\text { addressing the causes and effects of environmental } \\
\text { pollution }\end{array}$ & 3.644 & 0.645 & 6.701 & $17.700 \%$ & 0.000 & Moral \\
\hline $\begin{array}{l}\text { Reducing operational costs in order to achieve } \\
\text { competitive advantage and increase in profits and in } \\
\text { the incomes of employees }\end{array}$ & 3.474 & 0.528 & 8.173 & $15.198 \%$ & 0.000 & Moral \\
\hline $\begin{array}{l}\text { Protecting the community from the negative } \\
\text { environmental impacts of projects }\end{array}$ & 3.667 & 0.764 & 7.928 & $20.834 \%$ & 0.000 & Moral \\
\hline \multicolumn{7}{|l|}{ Investment, especially new. } \\
\hline Total & 3.637 & 0.501 & & $13.775 \%$ & 0.000 & Moral \\
\hline
\end{tabular}


TABLE 6 | Summary Descriptive Analysis

\begin{tabular}{|c|c|c|c|c|c|c|}
\hline The dimension & Mean & Std. Dev & T value & $\begin{array}{l}\text { Coefficient of } \\
\text { variation }\end{array}$ & Sig & $\begin{array}{l}\text { Statisticl } \\
\text { Decision }\end{array}$ \\
\hline Economic & 4.018 & 0.430 & 17.199 & $10.701 \%$ & 0.000 & Moral \\
\hline Environmental & 4.029 & 0.401 & 7.706 & $9.952 \%$ & 0.000 & Moral \\
\hline Social & 3.637 & 0.501 & 15.801 & $13.775 \%$ & 0.000 & Moral \\
\hline Total & $3-894$ & 0.287 & 18.648 & ------- & 0.000 & Moral \\
\hline
\end{tabular}

